\title{
Optimization of seed priming treatments to increase low-temperature germination rate
}

\author{
STUART P. HARDEGREE
}

Author is plant physiologist, USDA-Agricultural Research Service, Northwest Watershed Research Center, soo Park Blvd., Plaza IV, Suite 105, Boise, Ida. 83712, USA.

\begin{abstract}
Seeds of 4 range grass species were evaluated to determine the effects of priming-temperature, priming-water potential, and treatment-duration on subsequent germination response at $10^{\circ} \mathrm{C}$. Seeds of bluebunch wheatgrass [Pseudoroegneria spicata (Pursh) Löve], thickspike wheatgrass [Elymus lanceolatus (Scribn. and J.G. Smith) Gould; syn. Agropyron dasystachyum (Hook.) Scribn.], sandberg bluegrass (Poa sandbergii Vasey.), and bottlebrush squirreltail [Sitanion hystrix (Nutt.) J.G. Smith] were primed over the temperature range of 5 to $35^{\circ} \mathrm{C}$ and the water potential range of 0 to $-2.5 \mathrm{MPa}$ for up to 10 days to determine optimal priming conditions among all treatment combinations that did not result in premature radicle emergence from the seed coat. Most rapid germination of treated seeds was obtained at priming temperatures considered optimal for germination of untreated seeds. Optimal priming conditions were found to be at water potentials equal to, or less negative than, the threshold water potential at which radicle emergence was prevented for untreated seeds. Germination response data for untreated seeds can be used to simplify the estimation of optimal temperature and water potential conditions for seed priming.
\end{abstract}

Key Words: matric-priming, bluebunch wheatgrass, thickspike wheatgrass, sandberg bluegrass, bottlebrush squirreltail.

Native grasses and shrubs in the Great Basin are being replaced over large areas by cheatgrass (Bromus tectorum L.), a non-native weedy annual that proliferates after wildfire (Mack 1981, Young et al. 1987). One mechanism that may contribute to the competitive success of cheatgrass is the ability to germinate rapidly at low temperatures (Harris and Wilson 1970, Wilson et al. 1974). Seed priming, a presowing hydration technique that initiates ger-

Mention of a trademark or proprietary product does not constitute endorsement by the USDA and does not imply its approval to the exclusion of other products that may also be suitable.

Funding provided in part by the USDI Bureau of Land Management, Intermuantain Green tripping and Rehabilitation Project, under interagency agreement USDL/BLM 60-91H2-8-0020.

Manuscript accepted 20 May 1995. mination metabolism to a point short of radicle emergence, has been shown to increase low-temperature germination rate (Heydecker et al. 1975, Heydecker 1977, Heydecker and Coolbear 1977). Hardegree (1994a) used seed priming to induce 5 native grasses to germinate more rapidly than cheatgrass at $10^{\circ}$ $\mathrm{C}$ but only bluebunch wheatgrass [Pseudoroegneria spicata (Pursh) Löve], maintained as rapid a germination rate when the seeds were air-dried after priming. The priming treatments used by Hardegree (1994a) were derived from a previous study in which only a single priming water potential, 2 priming temperatures and 4 treatment durations were tested for each species (Hardegree 1994b). The purpose of this study was to determine optimal seed priming conditions for 4 Great Basin native perennial grasses over a much broader range of water potentials ( 0 to $2.5 \mathrm{MPa}$ ) and temperature regimes $\left(5\right.$ to $\left.35^{\circ} \mathrm{C}\right)$.

\section{Materials and Methods}

Blucbunch whcatgrass, thickspike wheatgrass [Elymus lanceolatus (Scribn. and J.G. Smith) Gould; syn. Agropyron dasystachyum (Hook.) Scribn.], sandberg bluegrass (Poa sandbergii Vasey.), and bottlebrush squirreltail [Sitanion hystrix (Nutt.) J.G. Smith] have been identified by the United States Department of Interior, Bureau of Land Management, as high priority species for restoration of deteriorated rangeland in the Great Basin. Seeds used in this study were collected in 1991 (Hardegree 1994a, 1994b). Each species was tested in a separate experimental run because the large number of treatments did not allow for simultaneous evaluation.

\section{Experiment 1}

Seeds were germinated over the water potential range of 0 to $2.5 \mathrm{MPa}$ and temperature range of 5 to $35^{\circ} \mathrm{C}$ to measure time requirements for radicle emergence from the seed coat. This experiment was conducted to eliminate from consideration in Experiment 2, combinations of temperature, water potential, and treatment duration expected to cause premature root growth during priming.

Seeds were germinated on top of cellulose membranes that were in contact with a reservoir of either water or an osmotic solution of polyethylene glycol 8000 (PEG) inside clear-plastic, 
snap-top vials (Hardegree and Emmerich 1992a). The cellulose membrane excluded PEG but allowed passage of water, thus, produced a matric-potential control surface at equilibrium with the osmotic potential of the solution reservoir. Polyethylene glycol was mixed with water to yield osmotic solutions having water potentials of $0,-0.1,-0.4,-0.7,-1.0,-1.3,-1.6,-1.9,-2.2$, and -2.5 MPa (Hardegree and Emmerich 1990). A separate set of osmotic solutions was mixed for each temperature regime to account for temperature effects on PEG solution water potential (Michel 1983). A previous study indicated that these species would not germinate at water potentials at or below $-2.5 \mathrm{MPa}$ for bluebunch wheatgrass, $-2.0 \mathrm{MPa}$ for thickspike wheatgrass, $-1.5 \mathrm{MPa}$ for bottlebrush squirreltail and -1.0 MPa for sandberg bluegrass (Hardegree 1994b). Bluebunch wheatgrass was, therefore, germinated over the water potential range of 0 to $-2.5 \mathrm{MPa}$ but thickspike wheatgrass and bottlebrush squirreltail were only germinated over the range of 0 to $-2.2 \mathrm{MPa}$ and sandberg bluegrass over the range of 0 to $-1.9 \mathrm{MPa}$.

Temperature regimes of $5,10,15,20,25,30$, and $35^{\circ} \mathrm{C}$ were randomly assigned among 14 environmental chambers, 2 for each temperature (Hardegree and Burgess 1995). Two germination vials for each combination of species, water potential and temperature were placed in each environmental chamber. Four sets of 30 seeds ( 35 for the smaller seeds of sandberg bluegrass) were placed in each vial and monitored for germination response for 21 days. Seeds were dusted with a fungicide powder (Daconil; 2,4,5,6-tetrachloro-1,3-benzenedicarbonitrile) at the beginning of the experiment. Germination response was monitored daily and seeds removed when radicle extension exceeded $2 \mathrm{~mm}$. Potential seed-priming treatments to be tested in Experiment 2 were selected from those combinations of temperature, water potential and treatment duration that resulted in minimal germination response ( $\leq 3 \%$ germination).

\section{Experiment 2 \\ Seed Priming}

Potential priming treatments identified in Experiment 1 were more numerous than could practically be tested. Priming conditions tested in this experiment were limited to treatment durations of $1,2,4,6,8$, and 10 days. An upper limit of 10 days was selected based upon previous observation that maximum germination occurred after 6-8 day priming duration for these species (Hardegree 1994b). The following water potentials were selected to test for priming effects at each temperature: $0,-0.1,-0.4,-1.0$, $1.6,-2.2$, and $-2.5 \mathrm{MPa}$ for thickspike wheatgrass and bluebunch wheatgrass; $0,-0.1,-0.4,-0.7,-1.0,-1.3$, and $-1.6 \mathrm{MPa}$ for bottlebrush squirreltail; and $0,-0.1,-0.4,-0.7,-1.0$, and $-1.3 \mathrm{MPa}$ for sandberg bluegrass. Four sets of $30-35$ seeds were primed at each combination of temperature, water potential, and treatment duration. Priming vials were distributed among 14 environmental chambers, 2 of which were maintained at each temperature. Treatment initiation was staggered so that all duration treatments terminated on the same day. Seeds were dusted with fungicide powder at the time they were loaded in the priming vials. After priming, the seeds were removed from the vials and air-dried at room temperature in the laboratory for 7 days (Hardegree 1994a).

\section{Germination Response}

Primed seeds were evaluated for germination response at $10^{\circ} \mathrm{C}$ using the same germination system as before except that pure water was used instead of PEG solution. Germination vials were arranged in 4 randomized blocks within a single, large environmental chamber. Germinating seeds received both fluorescent and incandescent light for 12 hours day ${ }^{-1}$. Twelve sets of control vials containing nontreated seeds were initiated at the beginning of each germination test. Twelve vials each of 3 nontreated cheatgrass accessions were also tested for germination response during each experimental run. The cheatgrass was collected from 3 field locations near Ten-mile Creek, Orchard, and Kuna Butte in southern Ada County, Ida., USA, during the year previous to the study. Germination response was monitored daily for 21 days and seeds were removed when radicle extension exceeded $2 \mathrm{~mm}$.

Two germination indices were calculated for the seeds in each vial: total germination percentage, and days to $50 \%$ germination. Quadratic regression equations were calculated to characterize post-treatment germination response for each germination index as a function of priming temperature, disregarding the influence of priming water potential and treatment duration. Regression equations were recalculated deleting non-significant $(P \leq 0.10)$ quadratic and linear terms. Non-significant, lower order terms were retained in the equation if a higher order term was significant. Germination indices were estimated from regression equations and a $95 \%$ prediction interval calculated for the individual species observations. Correlation analysis was used to evaluate the relationship between total germination percentage and days to $50 \%$ germination.

Additional analyses on the $25^{\circ} \mathrm{C}$-treatment data were used to
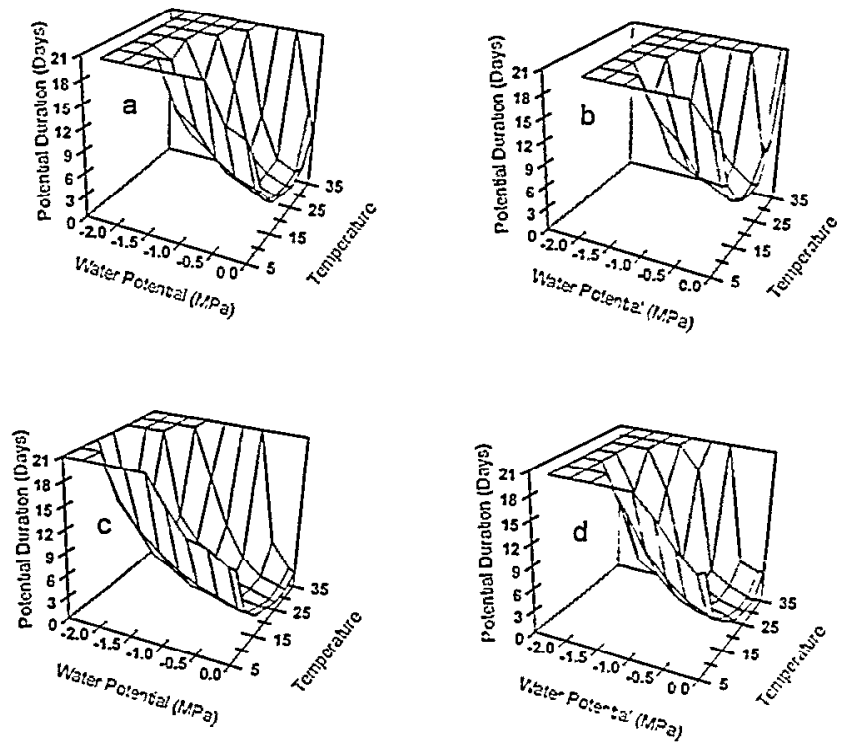

Fig. 1. Days required to reach $3 \%$ total germination for (a) bottlebrush squirreltail, (b) sandberg bluegrass, (c) bluebunch wheatgrass and (d) thickspike wheatgrass as a function of water potential and temperature. 

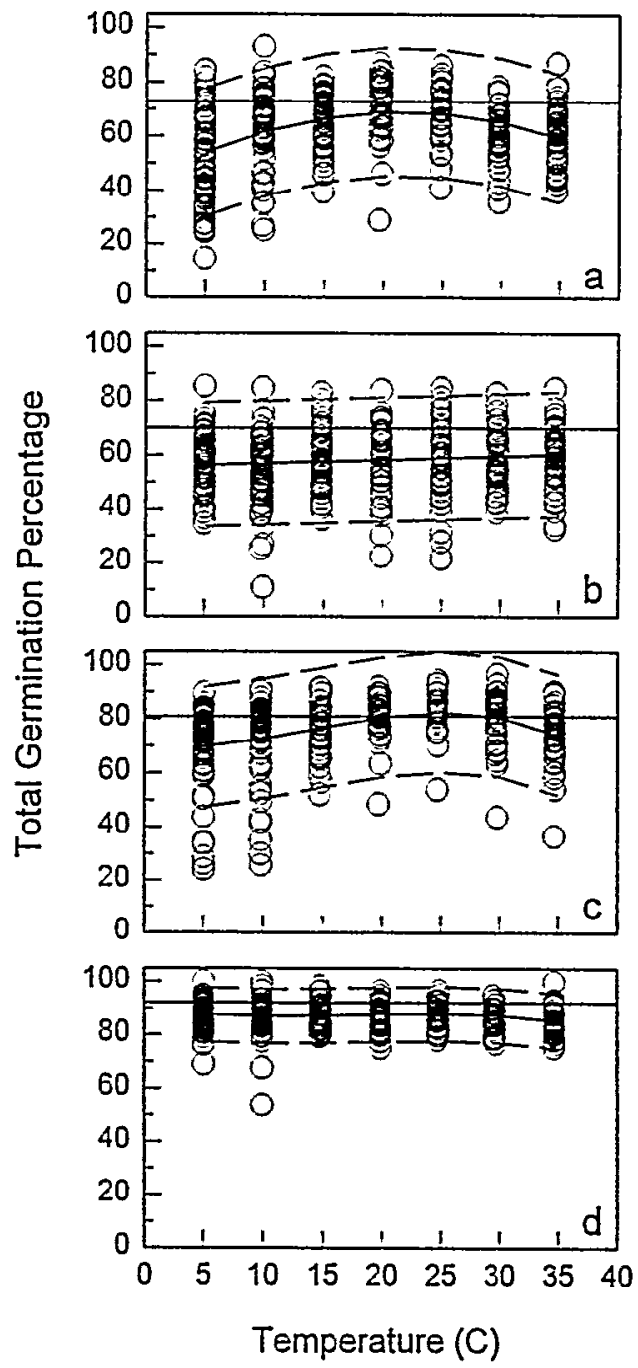

Fig. 2. Seed priming effect on total germination percentage at 10 ${ }^{-} \mathrm{C}$ as a function of priming temperature. Regression lines (solid) and 95\% confidence bands (dashed lines) were calculated from quadratic regression analysis for: a) bottlebrush squirreltail $\left(R^{2}=0.16\right)$; b) sandberg bluegrass $\left(R^{2}=0.01\right)$; c) bluebunch wheatgrass $\left(R^{2}=0.13\right)$; and $\left.d\right)$ thickspike wheatgrass $\left(R^{2}=0.01\right)$. Horizontal lines represent mean germination response of untreated seeds.

evaluate effects of priming water potential and treatment duration. Cubic response surfaces were calculated relating germination percentage and days to $50 \%$ germination to priming-treatment water potential and treatment duration. Regression equations were reculculated after deleting non-significant cubic, quadratic and linear terms. Non-significant lower order terms were retained as long as a single higher order term was significant. Germination index values were estimated from the regression equations and model confidence intervals $(P \leq 0.05)$ determined for the expected values for each treatment combination following the procedure outlined by Evans et al. (1982).

Mean germination response and $95 \%$ confidence intervals were calculated for the control treatments for each native species and for the different accessions of cheatgrass. Analysis of variance was used to test for differences in cheatgrass response as a func-
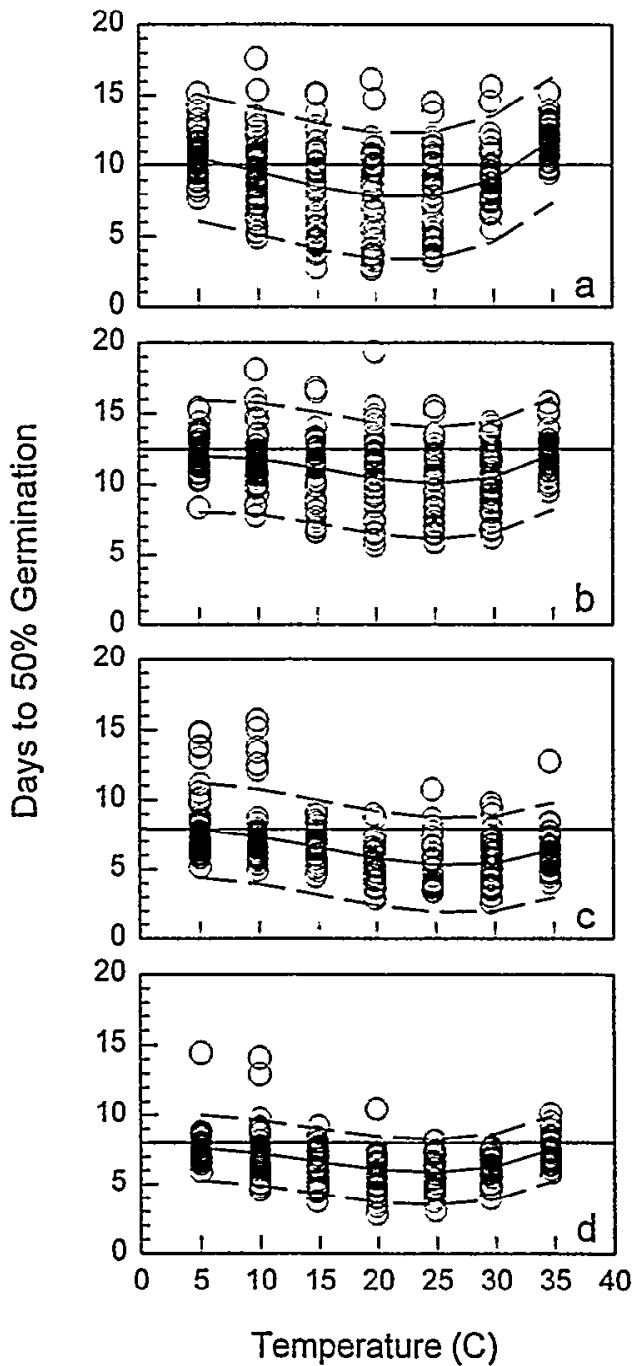

Fig. 3. Seed priming effect on days to $50 \%$ germination at $10^{\circ} \mathrm{C}$ as a function of priming temperature. Regression lines (solid) and $95 \%$ confidence bands (dashed lines) were calculated from quadratic regression analysis for: a) bottlebrush squirreltail $\left(R^{2}=0.26\right)$; b) sandberg bluegrass $\left(R^{2}=0.12\right)$; c) bluebunch wheatgrass $\left(R^{2}=0.22\right)$; and d) thickspike wheatgrass $\left(R^{2}=0.23\right)$. Horizontal lines represent mean germination response of untreated seeds.

tion of seed-lot and experimental run. Tukey's studentized range test was used to distinguish treatment differences among cheatgrass accessions.

\section{Results}

\section{Experiment 1}

Each species differed in the time required to reach $3 \%$ germination (Fig. 1). Bluebunch wheatgrass germinated most rapidly over the entire water potential and temperature range, followed by thickspike wheatgrass, bottlebrush squirreltail, and sandberg bluegrass. Any treatment combination that resulted in $>3 \%$ germination was eliminated from consideration as a potential priming treatment to be tested in Experiment 2. 
Table 1. Predicted values for total germination percentage of primed seeds as a function of priming water potential and treatment duration. Numbers in parentheses represent one-half confidence interval widths $(P \leq 0.05)$ calculated from the regression model.

\begin{tabular}{|c|c|c|c|c|c|c|c|c|c|}
\hline \multirow[t]{2}{*}{ Species } & \multirow{2}{*}{$\begin{array}{c}\text { Model } \\
\mathrm{R}^{2}\end{array}$} & \multirow{2}{*}{$\begin{array}{c}\text { Water } \\
\text { Potential }\end{array}$} & \multicolumn{7}{|c|}{ Treatment Duration } \\
\hline & & & 0 & 1 & 2 & 4 & 6 & 8 & 10 \\
\hline $\begin{array}{l}\text { Bottlebrush } \\
\text { squirreltail }\end{array}$ & 0.05 & $\begin{array}{c}\text { (MPa) } \\
0 \\
-0.1 \\
-0.4 \\
-0.7 \\
-1.0 \\
-1.3 \\
-1.6\end{array}$ & $73(6)^{1}$ & $\begin{array}{l}53(7) \\
57(5) \\
65(6) \\
66(5) \\
65(5) \\
64(6) \\
67(7)\end{array}$ & $\begin{array}{l}61(7) \\
66(5) \\
73(6) \\
74(5) \\
72(4) \\
71(5) \\
73(6)\end{array}$ & $\begin{array}{l}\overline{2} \\
\overline{-} \\
\overline{77}(5) \\
75(5) \\
77(5)\end{array}$ & $\begin{array}{l}- \\
\overline{-} \\
\overline{75}(5) \\
73(5) \\
74(5)\end{array}$ & $\begin{array}{l}- \\
- \\
\overline{73}(6) \\
69(5) \\
69(6)\end{array}$ & $\begin{array}{l}\overline{-} \\
\overline{-} \\
\overline{-} \\
75(8) \\
71(6) \\
70(8)\end{array}$ \\
\hline $\begin{array}{l}\text { Sundberg } \\
\text { bluegrass }\end{array}$ & 0.35 & $\begin{array}{c}0 \\
-0.1 \\
-0.4 \\
-0.7 \\
-1.0 \\
-1.3\end{array}$ & $70(8)$ & $\begin{array}{l}47(7) \\
47(6) \\
49(7) \\
54(7) \\
61(6) \\
71(9)\end{array}$ & $\begin{array}{l}50(6) \\
52(5) \\
58(5) \\
62(5) \\
65(4) \\
67(6)\end{array}$ & $\begin{array}{l}32(9) \\
41(7) \\
61(5) \\
71(6) \\
71(5) \\
62(7)\end{array}$ & $\begin{array}{l}- \\
- \\
\overline{68}(6) \\
74(5) \\
62(7)\end{array}$ & $\begin{array}{l}- \\
- \\
\overline{73}(6) \\
67(7)\end{array}$ & $\begin{array}{l}- \\
\overline{-} \\
\overline{69}(10) \\
78(11)\end{array}$ \\
\hline $\begin{array}{l}\text { Thickspike } \\
\text { wheatgrass }\end{array}$ & 0.05 & $\begin{array}{c}0 \\
-0.1 \\
-0.4 \\
-1.0 \\
-1.6 \\
-2.2 \\
-2.5\end{array}$ & $92(3)$ & $\begin{array}{l}86(4) \\
86(3) \\
87(3) \\
88(2) \\
89(2) \\
90(3) \\
91(4)\end{array}$ & $\begin{array}{l}- \\
- \\
88(3) \\
88(2) \\
88(2) \\
89(2) \\
89(3)\end{array}$ & $\begin{array}{l}- \\
- \\
- \\
90(5) \\
88(3) \\
87(2) \\
86(3)\end{array}$ & $\begin{array}{l}- \\
- \\
- \\
- \\
86(3) \\
84(3)\end{array}$ & $\begin{array}{l}\overline{-} \\
- \\
- \\
\overline{87}(3) \\
84(3)\end{array}$ & $\begin{array}{l}- \\
- \\
- \\
\overline{90}(5) \\
86(5)\end{array}$ \\
\hline
\end{tabular}

zero-day duration values sepresent mean germination percentages and confidence interval widths ( $\mathrm{P} \leq 0.05$ ) of nonprimed control treatments.

untested treatments due to premature radicle extension during priming.

\section{Experiment 2}

Figures 2 and 3 demonstrate gross priming-temperature effects on subsequent germination response at $10^{\circ} \mathrm{C}$ aggregated across priming-water potential and priming-duration treatments. The confidence bands given in these figures encompass $95 \%$ of the individual observations. Regression models for these data were significant at the $P \leq 0.01$ level except for the model for germination percentage of sandberg bluegrass, which was significant at the 0.02 level, and the model for germination percentage of thickspike wheatgrass which was significant at the 0.06 level. Priming increased germination rate (fewer days to $50 \%$ germination) but lowered total germination percentage, relative to the controls, for the majority of treatments tested.

Total germination percentage and days to $50 \%$ germination were negatively correlated for all species. Correlation analysis yielded $r$ values of -0.18 for thickspike wheatgrass, -0.58 for bluebunch wheatgrass, -0.46 for sandberg bluegrass and -0.41 for bottlebrush squirreltail. These data indicate that, in general, priming treatments that resulted in the highest germination percentages tended to also have the most rapid germination rates. Maximum germination percentage and germination rate were generally obtained in the priming-temperature region of $25^{\circ} \mathrm{C}$ (Figs. 2 and 3).

Priming water potential and treatment-duration effects on total germination percentage were not very dramatic for priming temperatures of $25^{\circ} \mathrm{C}$ (Table 1). Thickspike wheatgrass and bluebunch wheatgrass did not exhibit significant treatment effects for these variables. Total germination percentage of bottlebrush squirreltail and sandberg bluegrass was negatively affected by priming water potentials of 0 and $-0.1 \mathrm{MPa}$.

Water potential and treatment-duration effects on germination rate for seeds primed at $25^{\circ} \mathrm{C}$ werc significant and revealed some general patterns (Table 2). The wettest priming treatments were least effective and sometimes detrimental to subsequent germination rates. Increased treatment duration for seeds primed at or below $-0.4 \mathrm{MPa}$ resulted in fewer days to $50 \%$ germination, although, this trend began to reverse for some of the longer duration treatments of bottlebrush squirreltail and sandberg bluegrass. There was an apparent tradcoff between priming duration and water potential for bluebunch wheatgrass and thickspike wheatgrass. Wetter priming conditions tended to result in faster germination for these species but wetter conditions were limited to treatments of shorter duration. Longer priming duration tended to increase germination rate for these species but longer treatments were limited to drier priming conditions. Optimal priming conditions for thickspike wheatgrass and blucbunch wheatgrasses were found at intermediate water potentials and intermediate treatment durations. Optimal priming water potentials for these species would have resulted in germination during priming in a longer duration treatment. Most rapid germination rates for bottlebrush squirreltail and sandberg bluegrass were obtained by seeds primed at the least negative water potential shown to inhibit germination at $25^{\circ} \mathrm{C}$ in Experiment $1(-1.3 \mathrm{MPa}$ for bottlebrush squirreltail and -1.0 MPa for sandberg bluegrass, Fig. 1).

The 3 cheatgrass accessions were evaluated for germination response at $10^{\circ} \mathrm{C}$ during each run of Experiment 2. None of the cheatgrass seedlots could be distinguished by significant differences $(P \leq 0.05)$ either within or between experimental runs. 
Table 2. Predicted values for days to $50 \%$ germination of primed seeds as a function of priming water potential and treatment duration. Numbers in parentheses represent one-half confidence interval widths $(P \leq 0.05)$ calculated from the regression model.

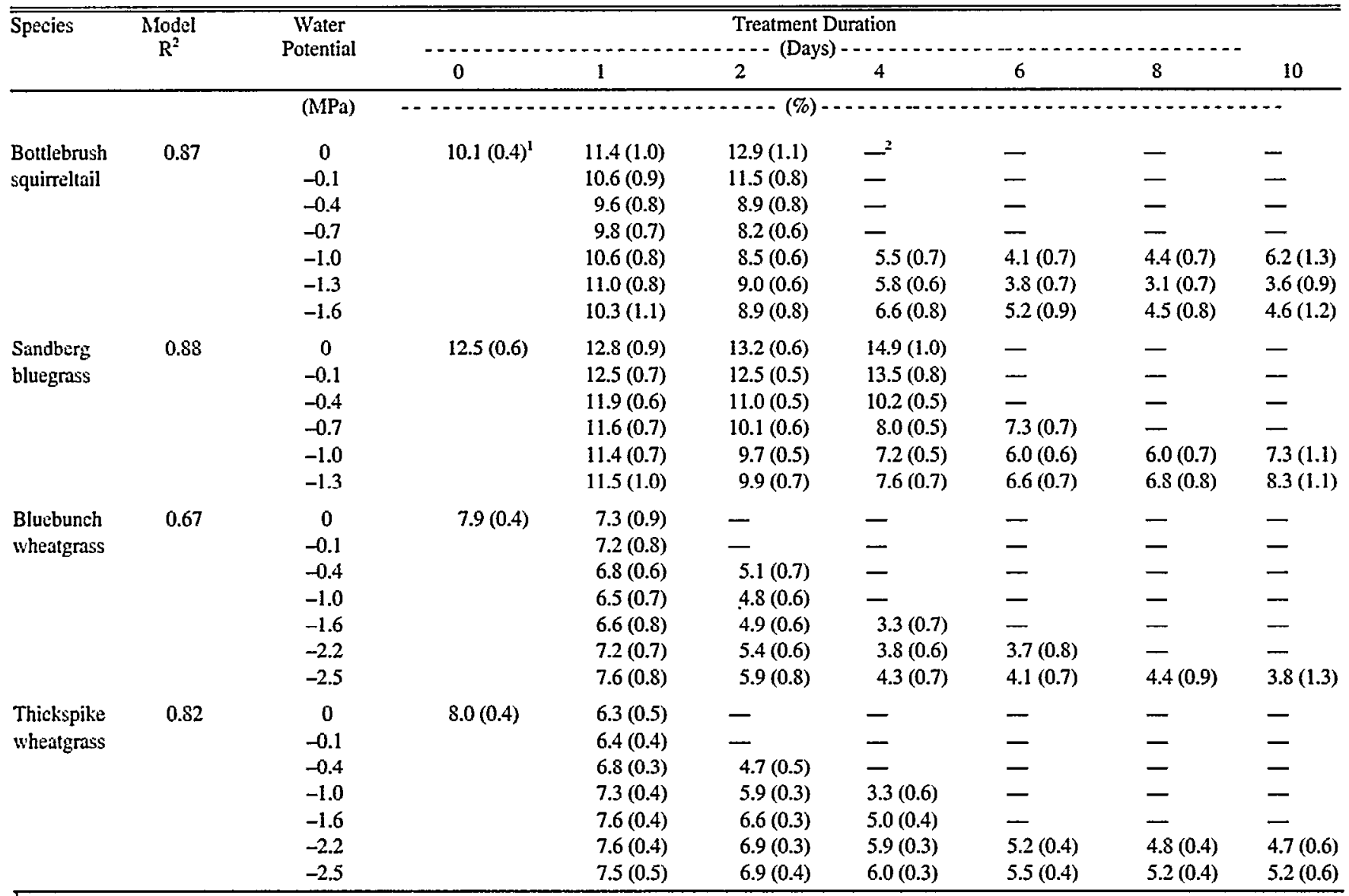

zero-day duration values represent mean days to $50 \%$ germination and confidence interval widths ( $\mathrm{P} \leq 0.05$ ) of nonprimed control treatments.

2 untested treatments due to premature radicle extension during priming.

Mean days to $50 \%$ germination across all seed lots and experimental runs was about 4 days. Total germination percentages for the cheatgrass accessions were $71 \%$ for Kuna, $69 \%$ for Orchard and $56 \%$ for Tenmile Creek. The Tenmile creek seedlot had significantly lower total germination percentage than the other accessions.

\section{Discussion}

A wide variety of presowing hydration treatments have been used to enhance seed germination response. These treatments include equilibration under conditions of high humidity (Perl and Feder 1981, Finnerty et al. 1992), soaking in water (Bleak and Keller 1974, A-As-Aqui and Carleto 1978, Coolbear and McGill 1990) or osmotic solution (Heydecker et al. 1975, Knypl and Khan 1981), equilibration with a matric-potential control surface (Gray et al. 1990, Hardegree and Emmerich 1992a, 1992b), intermixture with a porous matrix (Peterson 1976, Taylor et al. 1988, Khan et al. 1992), and simple water addition to subgermination water content (Austin et al. 1969; Lush et al. 1981). The main objective of these treatments is to allow water uptake and germination metabolism to proceed to a point just short of radicle extension (Bradford 1986, Heydecker and Coolbear 1977).
Treated seeds exhibit more rapid germination which is usually expressed to a greater degree at sub-optimal germination temperatures (Heydecker 1977). Germination enhancement has been attributed to metabolic repair processes, a buildup of germination metabolites or osmotic adjustment during treatment (Coolbear et al. 1980, Bradford 1986, Bray et al. 1989). The degree of enhancement depends upon the temperature, water potential, duration, and other conditions specific to the treatment medium (Heydecker and Coolbear 1977). Some long duration, low water potential, and/or high temperature priming treatments can have a negative effect on subsequent germination response (Coolbear et al. 1980, Ely and Heydecker 1981, Gray et al. 1990, Hardegree and Emmerich 1992a, 1992b).

Presowing seed hydration treatments are limited to those conditions that do not result in premature radicle extension (Heydecker and Coolbear 1977). This limitation does not greatly narrow the range of potential treatment combinations that could be tested to determine optimal priming conditions. Previous studies have estimated optimal priming conditions to occur at the least negative water potential that prevents radicle emergence during a preliminary germination experiment (Evans and Pill 1989, Dell'Aquila and Tritto 1990, Hardegree 1994b). In this experiment, optimal priming conditions for 2 of the species, bluebunch wheatgrass and thickspike wheatgrass were obtained at water potentials that were less negative than this water potential threshold. The seeds 
of both species would have exhibited root growth had the priming duration been extended from 4 days to 6 days (Table 2).

Information derived from the priming response pattern of these species can be used to limit the number of temperature, water potential, and duration combinations that need to be tested in other seedlots. Maximum germination rates in this experiment were obtained for seeds primed at a temperature that was also near-optimal for germination of untreated seeds. A first step in estimating optimal priming conditions may be to conduct a test to determine the optimal germination temperature for untreated seeds germinated in water. The second step would be to germinate seeds at the optimal temperature but over a range of water potentials to determine time requirements for radicle emergence. The third step would be to conduct an actual priming test at selected water potentials but only for treatment durations that approached, but do not result in, radicle emergence. The water potential range for the priming test should be further limited to those treatments at, or less negative than, the threshold water potential beyond which radicle extension was prevented at the longest treatment duration in the previous germination test.

Young and Evans (1982) predicted that germination advancement of only a few days might make a difference in grass seedling survival. A previous study of native grass seeds showed that seed priming reduced the germination time at $10^{\circ} \mathrm{C}$ by 4 to 8 days for freshly primed seeds and 2 to 6 days for seeds that were redried after priming (Hardegree 1994a). Optimization of priming treatments resulted in faster germination for primed and dried seeds of 3 of the 4 seedlots that were also tested in the previous study. Bluebunch wheatgrass, thickspike wheatgrass and bottlebrush squirreltail were also induced to germinate in less than the 4 day germination requirement for cheatgrass at $10^{\circ} \mathrm{C}$. Future research must be conducted to determine whether these levels of germination enhancement can be expected to result in better field establishment.

\section{Literature Cited}

A-As-Aqui and A. Carleto. 1978. Effect of seed presowing hardening on seedling emergence of four forage species. Seed Sci. Tech. 6:701-709.

Austin, R.B., P.C. Longden, and J. Hutchinson. 1969. Some effects of hardening carrot seed. Ann. Bot. 33:883-895.

Bleak, A.T. and W. Keller. 1974. Emergence and yield of six range grasses planted on four dates using natural and treated seed. J. Range Manage. 27:225-227.

Bradford, K.J. 1986. Manipulation of seed water relations via osmotic priming to improve germination under stress conditions. HortSci. 21:1105-1112.

Bray, C.M., P.A. Davison, M. Ashraf, and R.M. Taylor. 1989. Biochemical changes during osmopriming of leek seeds. Ann. Bot. 63:185-193.

Coolbear, P., D. Grierson, and W. Heydecker. 1980. Osmotic pre-sowing treatments and nucleic acid accumulation in tomato seeds (Lycopersican lycopersicum). Seed Sci. Tech. 8:289-303.

Coolbear, P. and C.R. McGill. 1990. Effects of a low-temperature presowing treatment on the germination of tomato seed under temperature and osmotic stress. Sci. Hort. 44:43-54.

Dell'Aquila, A. and V. Tritto. 1990. Aging and osmotic priming in wheat seeds: Effects upon certain components of seed quality. Ann. Bot. 65:21-26.

Ely, P.R. and W. Heydecker. 1981. Fast germination of parsley seeds. Sci. Hort. 15:127-136.
Evans, R.A., D.A. Easi, D.N. Book, and J.A. Young. 1982. Quadratic response surface analysis of seed-germination trials. Weed Sci. 30:411-416.

Evans, T.A., and W.G. Pill. 1989. Emergence and seedling growth from osmotically primed or pregerminated seeds of asparagus (Asparagus officinalis L.). J. Hort. Sci. 64:275-282.

Finnerty, T.L., J.M. Zajicek, and M.A. Hussey. 1992. Use of seed priming to bypass stratification requirements of three Aquilegia species. HortSci. 27:310-313.

Gray, D., J.R.A. Steckel, and L.J. Hands. 1990. Responses of vegetable seeds to controlled hydration. Ann. Bot. 66:227-235.

Hardegree, S.P. 1994a. Drying and storage effects on germination of primed grass seeds. J. Range Manage. 47:196-199.

Hardegree, S.P. 1994b. Matric priming increases germination rate of Great Basin native perennial grasses. Agron. J. 86:289-293.

Hardegree, S.P. and M.D. Burgess. 1995. Datalogger control of environmental chambers for variable-temperature germination experiments. J. Range Manage. 48.554-556

Hardegree, S.P. and W.E. Emmerich. 1990. Effects of polyethylene glycol exclusion on the water potential of solution-saturated filter paper. Plant Physiol. 92:462-466.

Hardegree, S.P. and W.E. Emmerich. 1992a. Effect of matric-priming duration and priming water potential on germination of four grasses. $J$. Exp. Bot. 43:233-238.

Hardegree, S.P. and W.E. Emmerich. 1992b. Seed germination response of four southwestern range grasses to equilibration at subgermination matric-potentials. Agron. J. 84:994-998.

Harris, G.A. and A.M. Wilson. 1970. Competition for moisture among seedlings of annual and perennial grasses as influenced by root elongation at low temperature. Ecol. 51:530-534.

Heydecker, W. 1977. Stress and seed gemination: an agronomic view, p. 237-282. In: A.A. Khan (ed.), The physiology and biochemistry of seed dormancy and germination. Elsevier/North-Holland Biomedical Press, Amsterdam.

Heydecker, W. and P. Coolbear. 1977. Seed treatments for improved performance - survey and attempted prognosis. Seed Sci. Tech. $5: 353-425$.

Heydecker, W., J. Higgins, and Y.J. Turner. 1975. Invigoration of seeds? Seed Sci. and Tech. 3:881-\$88.

Khan, A.A., J.D. Maguire, G.S. Abawi, and S. Ilyas. 1992. Matriconditioning of vegetable seeds to improve stand establishment in early field plantings. J. Amer. Soc. Hort. Sci. 117:41-47.

Knypl, J.S. and A.A. Khan. 1981. Osmoconditioning of soybean seeds to improve performance at suboptimal temperatures. Agron. J. 73:112-116.

Lush, W.M., R.H. Groves, and P.E. Kaye. 1981. Pre-sowing hydration treatments in relation to seed germination and early seedling growth of wheat and ryegrass. Aust. J. Plant Physiol. 8:409-425.

Mack, R.N. 1981. Invasion of Bromus tectorum L. into western North America: an ecological chronicle. Agro-Ecosys. 7:145-165.

Michel, B.E. 1983. Evaluation of the water potentials of solutions of polyethylene glycol 8000 both in the absence and presence of other solutes. Plant Physiol. 72:66-70.

Perl, M. and Z. Feder. 1981. Improved seedling development of pepper seeds (Capsicum annum) by seed treatment for pregermination activities. Seed Sci. Tech. 9:655-663.

Peterson, J.R. 1976. Osmotic priming of onion seeds - the possibility of a commercial scale treatment. Sci. Hort. 5:207-214.

Taylor, A.G., D.E. Klein, and T.H. Whitlow. 1988. SMP: solid matrix priming of seeds. Sci. Hort. 37:1-11.

Wilson, A.M., D.E. Wondercheck, and C.J. Goebel. 1974. Responses of range grass seeds to winter environments. J. Range Manage. 27:120-122.

Young, J.A. and R.A. Evans. 1982. Temperature profiles of cool season range grasses. ARR-W-27. USDA-ARS, Western Region, Oakland, Calif.

Young, J.A., R.A. Evans, R.E. Eckert, and B.L. Kay. 1987. Cheatgrass. Rangelands 9:266-270. 